\title{
Factors Associated with Minimum Acceptable Diet in 6-11-Month- Old Indonesian Children Using the 2017 IDHS
}

\author{
Eurika Zebadia $^{1}$ D, Trias Mahmudiono ${ }^{1 *}$ (D) Dominikus Raditya Atmaka ${ }^{1}$, Mira Dewi ${ }^{2}$, Siti Helmyati $i^{3}$, Cindra Tri Yuniar ${ }^{4}(\mathbb{D}$ \\ ${ }^{1}$ Department of Nutrition, Faculty of Public Health, Universitas Airlangga, Surabaya, Jawa Timur, Indonesia; ${ }^{2}$ Department of \\ Community Nutrition, Faculty of Human Ecology, IPB University, Bogor, Indonesia; ${ }^{3}$ Department of Health Nutrition, Faculty \\ of Medicine, Public Health and Nursing, Universitas Gajah Mada, Yogyakarta, Indonesia; ${ }^{4}$ Department of Pharmacology and \\ Clinical Pharmacy, School of Pharmacy, Institut Teknologi Bandung, Kota Bandung, Jawa Barat, Indonesia
}

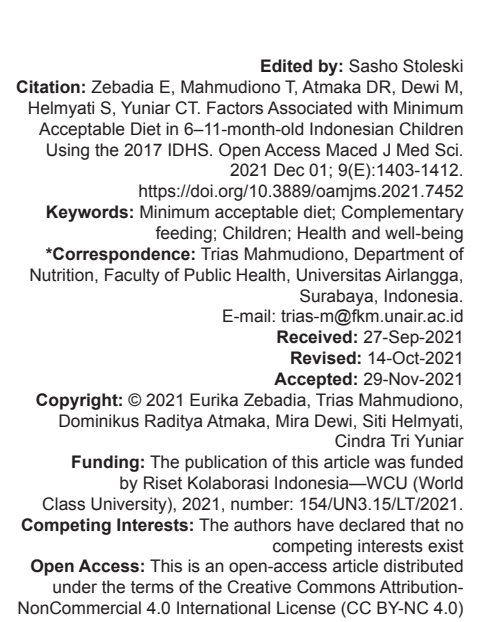

\section{Abstract}

BACKGROUND: Inadequate complementary feeding practices are known to contribute to children's nutritiona status. A minimum acceptable diet (MAD) is one of the simple, valid, and reliable indicators to assess complementary feeding practices in 6-23-month-old children on food diversity and meal frequency. Based on the UNICEF data, the MAD of 6-11 months in Indonesia was $26.3 \%$ in 2017 and the lowest compared to other groups. Hence, this study research question is posing toward several factors associated with the low MAD among 6-11 months infant.

AIM: This study aimed to determine factors associated with MAD in 6-11-month-old children in Indonesia.

METHODS: This study was a secondary analysis using the 2017 Indonesia Demographic and Health Survey. This is a cross-sectional study involving 17,848 children in Indonesia. Final sample to be analyzed were 1,441 children of 6-11-month-old. Logistic regression model was applied to identify the significant risk factors associated with MAD.

RESULTS: The result showed that the prevalence of MAD in this study is $29 \%$. From the multivariate logistic regression, wealth index, television ownership, and mother's occupation were significantly associated with MAD of 6-11-month-old children in Indonesia.

CONCLUSION: In conclusion, factors associated with MAD among 6-11-month-old children were wealth index television ownership, and mother's occupation.

\section{Introduction}

Undernutrition is still a big nutritional problem in Indonesia. The latest nutritional status survey on children under five in Indonesia (Survei Status Gizi Balita Indonesia) showed that $16.29 \%$ of children were underweight, $27.67 \%$ were stunted, and $7.44 \%$ were wasted [1]. Undernutrition occurred due to the direct, underlying, and base causes. The direct causes of malnutrition were insufficient intake and disease that were caused by underlying causes including household food insecurity, unhealthy living environment, inadequate health facility, and inadequate feeding practices [2], [3], [4].

In 2008, the WHO and UNICEF created indicators to assess the infant and young child feeding (IYCF) practices [5], [6], [7]. There are eight core indicators to assess the IYCF practices that are mainly designed for use in large-scale surveys or national programs. One of the eight indicators is minimum acceptable diet (MAD). The MAD is one of the eight indicators that are simple, valid, and reliable to assess IYCF practices in the population level. This indicator consists of two other core indicators, minimum dietary diversity (MDD) and minimum meal frequency (MMF). MDD is defined as a child who ate $\geq 5$ food groups in the previous day, whereas MMF is defined as a child who was given food that fulfills the minimum criteria [3], [4]. The criteria of MMF are different by the age and the breastfeeding status. In breastfed children aged 6-8 months, the minimum frequency is 2 times. Meanwhile, the minimum frequency of 9-23 breastfed children is 3 times and for the nonbreastfed children aged 9-23-monthold is 4 times [3], [5], [6]. The child who ate diverse food and was given food in an adequate frequency is considered to meet the MAD. Therefore, MAD is defined as a proportion of children aged 6-23 months who receive the MDD and MMF [4], [5]. The global achievement of MAD is $15.9 \%$ [6]. Meanwhile, the 
South East Asia and Indonesia's achievement of MAD in $6-23$-month-old children is $41 \%$ and $40.3 \%$, respectively [8], [9], [10].

According to the UNICEF Global Database of IYCF, the latest survey to determine the MAD in Indonesia was the Indonesia Demographic and Health Survey (IDHS) held in 2017 in 34 provinces of Indonesia. From this survey, the achievement of MAD varies within the age group. The MAD prevalence in children aged 6-11 months, 12-15 months, 16-19 months, and $20-23$ months is $26.3 \%, 46 \%, 45.7 \%$, and $50.5 \%$, respectively [10]. The prevalence in 6-11 months was the lowest among all age group. Compared to the prevalence of MAD on the IDHS that was held in 2012, an approximately $5 \%$ increment was found in most of the older age group except in the 6-11-month-old group. In 2012, the prevalence of MAD was $25.7 \%$ [10]. Within 5 years, the prevalence of MAD in children aged $6-11$ months is $26.3 \%$, thus showing that the increment is only $0.6 \%$.

The basic causes of undernutrition are social, economic, and political aspects that also could affect the feeding practices [2]. One of the indicators used to determine the economic status of household is wealth index. Studies in Indonesia and different countries showed that wealth index is one of the factors that are associated with MAD [11], [12], [13], [14]. Furthermore, social, economic, and political aspects could affect the household's access to several resources including education, income, employment, technologies, and land [2]. Other studies also showed that a correlation was found between parent's education and MAD [14], [15], [16]. Mothers who have higher educational level will have a better practice of complementary feeding due to the ability to understand the benefit of MAD [17], [18]. The household access to information also affects the MAD due to the exposure of information including television, radio, and newspaper, which will increase mother's knowledge on child's feeding practices [19]. The household that has frequent exposure to media is also associated with MAD achievement [19], [20], [21]. The parental employment status was also associated with MAD in previous studies [11], [22]. Working parents will contribute to the household's income but will also affect the parent's involvement in child feeding [11].

The previous studies on the MAD in Indonesia had been conducted before using the population of 6-23-month-old children in one of the 34 provinces in Indonesia, whereas the present study is representative of the national survey scale data [20], [21]. Based on these findings, this study aimed to determine factors associated with MAD in 6-11-month-old children in Indonesia. Better understanding on the determinants of the low prevalence in children aged 6-11 months is needed to increase the MAD prevalence.

\section{Materials and Methods}

\section{Study settings}

The IDHS was conducted on July 24-September 30, 2017, in the 33 provinces in Indonesia. The 2017 IDHS was implemented by Statistics Indonesia in collaboration with the National Population and Family Planning Board and the Ministry of Health (MoH) [22].

\section{Study design and population of interest}

A cross-sectional study design was used in this study. This study used secondary data that were obtained from the 2017 IDHS that was accessed from the demographic and health survey public domain. The study population in this study included all families in Indonesia who had 6-11-month-old children. According to Statistics Indonesia, the number of 1-11 months children in Indonesia on 2017 were 4,746,438 [23].

\section{Sample}

The 2017 IDHS samples were obtained from 1.970 census blocks spread in rural and urban areas. Two stages of stratified sampling have been identified. The first stage was to select the census block. The census blocks were selected using a system that is proportional to size and is classified based on the urban or rural area and wealth index. The second stage was for household selection. From each census block, 25 households were selected using systematic sampling. After that, eight households were selected from the previously selected households using systematic sampling to obtain samples of married men [23]. The number of samples was calculated by considering the relative standard error (RSE) values of selected basic variables in the 2017 IDHS. The minimum number of sampled households was calculated using an average RSE of $3.5 \%$. The sample size was corrected using the compromise allocation method approach and was adjusted with nonresponse response of $5 \%$. The expected sample was 49,250 households, with 25,300 and 23,950 households from urban and rural areas, respectively. The 25 household samples were expected to obtain 59,100 15-49-year-old women [24].

The number of eligible women aged 15-49 years who were interviewed was 49,627 [23]. The data of interviewed women who had children were recorded on the children's record (IDKR71FL) dataset ( $n=17,848$ ) that contains information related to the child's pregnancy and postnatal care, immunization, and health. A number of 1,691 eligible women aged 15-49 years interviewed with their last-born child aged 6-11 months were obtained. Cases with missing values and did not meet the inclusion criteria were 
deleted from the dataset. The final subpopulation in this study is 1,441 . Figure 1 will explain the sampling procedure.

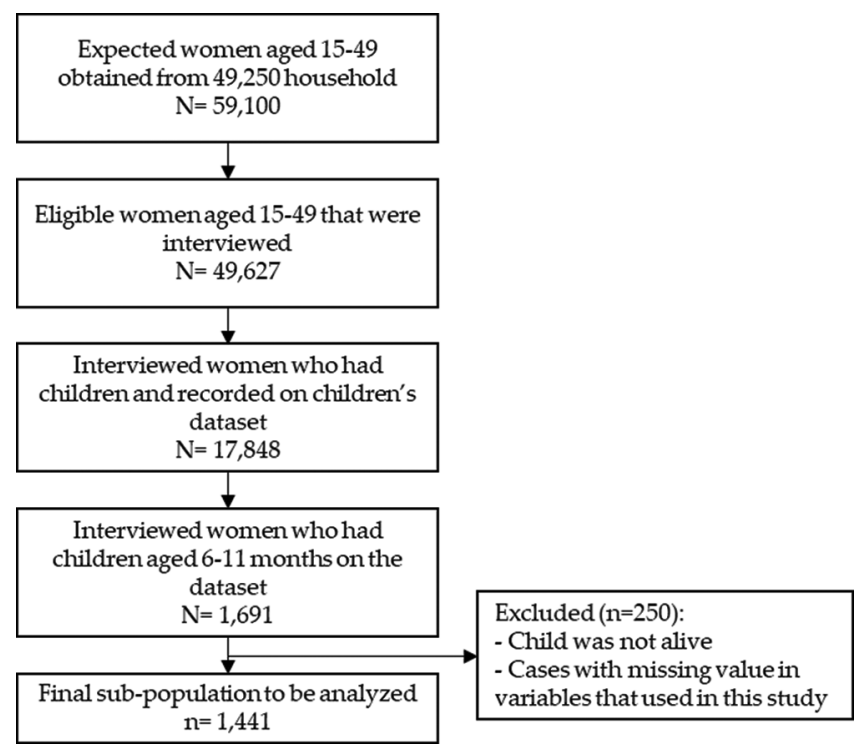

Figure 1: Sampling procedure flow diagram

\section{Inclusion and exclusion criteria}

The inclusion criteria of this study included still alive children aged 6-11 months and who have complete data in variables that are related to dietary diversity, meal frequency, parent's educational level, access to information, parent's occupation, sanitation, child care practices, and access to health facilities. All cases that did not meet the inclusion criteria were excluded from the study.

\section{Data collection}

The 2017 IDHS was a national scale survey. The primary data of the 2017 IDHS were collected on July 24-September 30, 2017. The data were collected using four questionnaires, which included the household questionnaire, woman's questionnaire, man's questionnaire, and unmarried man's questionnaire. The household and women questionnaires were based on the standard DHS phase 7 questionnaires but were adapted for use in Indonesia. The questionnaire was pretested in several places in Indonesia. To collect the data, 145 interviewing teams had been trained [24].

The dataset was obtained from the demographic and health survey public domain (https://dhsprogram. $\mathrm{com} /$ ). The data were requested on November 9, 2020 using project title "MAD in Indonesia" and requesting access for Indonesia data. The request was accepted on November 10, 2020. After the permission was granted by DHS, the dataset that was used in this study was IDKR71FL or children's record file. This dataset contains the information related to the child's pregnancy and postnatal care, immunization, and health.

\section{Dependent variables of the study}

The dependent variable in this study was the MAD. MAD refers to the proportion of children who had at least the MDD and MMF during the previous day for breastfed children and received at least two milk feedings and had at least the MDD and MMF during the previous day for nonbreastfed children [7].

MDD refers to children who were fed with 5 out of 8 groups in the previous day. The food groups included (1) grains, roots, and tubers, (2) legumes and nuts, (3) dairy products (milk, yogurt, cheese), (4) flesh foods (meat, fish, poultry, and liver/organ meats), (5) eggs, (6) vitamin A-rich fruits and vegetables, (7) other fruits and vegetables, and (8) breast milk [25]. MMF refers to children who received solid, semisolid, or soft foods that fulfill the minimum criteria [8]. The minimum criteria for MMF were divided based on age and breastfeeding status. For children who were breastfed and aged 6-8 months, the mini-mum requirement is 2 times/day. The minimum requirement for children aged 9-23 months and who were breastfed is 3 times/day. Meanwhile, the requirement for children aged $6-23$ months who are not breastfed is 4 times a day [7], [8].

\section{Independent variables of the study}

The independent variables in this study were parent's educational level, parent's occupation, sanitation, access to information, wealth index, and access to health facilities.

\section{Data entry and analysis}

To construct the MAD variable, constructing the MDD and MMF variables first is important by computing variables that were related to MDD and MMF that can be seen in Table 1. After the MDD and MMF variables were constructed, the MAD variable could be constructed. The MAD variable was classified as met and not met. Children were classified as met MAD variable if they met the MAD and MMF. For nonbreastfed children, the additional requirement to meet the MAD was that the children received minimum 2 times of milk feeding.

A descriptive analysis was performed to see the sample characteristic and the prevalence of MAD. Subsequently, bivariate analyses were conducted to determine the associations between the independent and dependent variables (MAD). The bivariate analyses for the independent variables were performed at $p<0.05$ using bivariate logistic regression. Multivariate logistic regression analyses were performed to determine the association between the independent variables and MAD to see the effects of other relevant factors and covariates. The independent variables found to be significantly associated with the dependent variable in the bivariate analyses were used in the multivariate 
Table 1: Variables used to construct the MAD

\begin{tabular}{|c|c|c|c|}
\hline \multirow[t]{2}{*}{ Indicators } & \multirow[t]{2}{*}{ Food group } & \multicolumn{2}{|c|}{ Variables in IDKR71FL dataset } \\
\hline & & Variables & Labels \\
\hline \multirow[t]{17}{*}{ MDD } & Breastmilk & M4 & Duration of breastfeeding \\
\hline & Grains, roots, and & V12A & Gave child fortified baby food \\
\hline & tubers & V414E & $\begin{array}{l}\text { Gave child bread, noodles, other made } \\
\text { from grains }\end{array}$ \\
\hline & & V414F & $\begin{array}{l}\text { Gave child potatoes, cassava, or other } \\
\text { tubers }\end{array}$ \\
\hline & Legumes and nuts & V4140 & $\begin{array}{l}\text { Gave child food made from beans, } \\
\text { peas, lentils, nuts }\end{array}$ \\
\hline & $\begin{array}{l}\text { Dairy products (milk, } \\
\text { yogurt, cheese) }\end{array}$ & V411 & $\begin{array}{l}\text { Gave child tinned, powdered, or fresh } \\
\text { milk }\end{array}$ \\
\hline & & V411A & Gave child baby formula \\
\hline & & V414V & Gave child yogurt \\
\hline & & V414P & $\begin{array}{l}\text { Gave child cheese, yogurt, other milk } \\
\text { products }\end{array}$ \\
\hline & $\begin{array}{l}\text { Flesh foods (meat, fish, } \\
\text { poultry, and liver/organ }\end{array}$ & V414H & $\begin{array}{l}\text { Gave child meat (beef, pork, lamb, } \\
\text { chicken, etc.) }\end{array}$ \\
\hline & meats) & V414M & Gave child liver, heart, other organs \\
\hline & & V414N & Gave child fish or shellfish \\
\hline & Eggs & V414G & Gave child eggs \\
\hline & $\begin{array}{l}\text { Vitamin A-rich fruits and } \\
\text { vegetables }\end{array}$ & V414I & $\begin{array}{l}\text { Gave child pumpkin, carrots, squash } \\
\text { (yellow or orange inside) }\end{array}$ \\
\hline & & V414J & $\begin{array}{l}\text { Gave child any dark green leafy } \\
\text { vegetables }\end{array}$ \\
\hline & & V414K & $\begin{array}{l}\text { Gave child mangoes, papayas, other } \\
\text { vitamin A-rich fruits }\end{array}$ \\
\hline & $\begin{array}{l}\text { Other fruits and } \\
\text { vegetables }\end{array}$ & V414L & Gave child any other fruits \\
\hline \multirow[t]{4}{*}{ MMF } & & M39 & $\begin{array}{l}\text { Number of times ate solid, semisolid, } \\
\text { or soft food yesterday }\end{array}$ \\
\hline & & V469E & $\begin{array}{l}\text { Times gave child powdered/tinned/ } \\
\text { fresh milk }\end{array}$ \\
\hline & & V469F & Times gave child infant formula \\
\hline & & V469X & Times gave child yogurt \\
\hline
\end{tabular}

logistic regression modeling at $p<0.05$. Odds ratios and $95 \%$ confidence intervals $(\mathrm{Cl})$ were reported at $p<0.05$ level of significance. In the analysis process, the parent's occupation variables were reduced into three sub-variables. The sub-variables are not working, working in agricultural section, and working in nonagricultural section.

\section{Results}

\section{Characteristics of the study population}

This study included 1,441 cases. The child's mean age in this study was $( \pm S D) 8.51 \pm 1.69$ months. Most of the children in this study lived in Java Island $(31.5 \%)$, Indonesia, which is the most populated island. A number of children (5.8\%) were born with low birth weight, whereas 1,357 children $(94.2 \%)$ were born weighing $\geq 2,500 \mathrm{~g}$. Most of the children $(81.8 \%)$ did not experience diarrhea in the past 2 months (Table 1). Most of the children lived in households that have television $(82.1 \%)$ and watch television at least once a week $(80.8 \%)$. Most households in this study owned a mobile telephone (580.4\%). Over half of the cases were not using the internet in the last month $(51.3 \%)$, but $35.2 \%$ used it almost every day. Most of the households were in the poorest $(23 \%)$ category of the wealth index (Table 2). The father's occupation in this study was mostly agricultural or self-employed (24.1\%). Meanwhile, half of the mothers in this study were not working (53.6\%). Fathers and mothers' highest
Table 2: Characteristics of the children

\begin{tabular}{lll}
\hline Characteristics & Frequency $(\mathrm{n}=1,441)$ & Percentages \\
\hline Age in months & & \\
6 & 232 & 16.1 \\
7 & 206 & 14.3 \\
8 & 241 & 16.7 \\
9 & 267 & 18.5 \\
10 & 244 & 16.9 \\
11 & 251 & 17.4 \\
Child's sex & & \\
Male & 787 & 54.6 \\
Female & 654 & 45.4 \\
Location & & \\
$\quad$ Sumatra & 387 & 26.9 \\
Java & 454 & 31.5 \\
Bali, East Nusa Tenggara, West Nusa Tenggara & 130 & 9.0 \\
Borneo & 134 & 9.3 \\
$\quad$ Sulawesi & 219 & 15.2 \\
Papua and Maluku & 117 & 8.1 \\
Currently breastfed & & \\
$\quad$ Yes & 1,198 & 83.1 \\
$\quad$ No & 243 & 16.9 \\
History of diarrhea & & \\
$\quad$ No & 1,179 & 81.8 \\
Yes, last 2 weeks & 262 & 18.2 \\
Birth weight & & \\
$\quad<2,500 \mathrm{~g}$ & 84 & 5.8 \\
$\geq 2,500 \mathrm{~g}$ & 1,357 & 94.2 \\
\hline${ }^{*}$ Mean child age was $8.51 \pm 1.69$ months. & &
\end{tabular}

educational level was mostly graduated from senior high school, respectively, $38.4 \%$ and $35.7 \%$. Over $70 \%$ of households in this study had private toilet facilities with septic tanks, and $81.8 \%$ of the children did not have diarrhea in the last 2 weeks (Tables 3 and 4).

Table 3: Characteristics of the household

\begin{tabular}{|c|c|c|}
\hline Characteristics & Frequency $(n=1,441)$ & Percentages \\
\hline \multicolumn{3}{|l|}{ Household has television } \\
\hline No & 198 & 13.7 \\
\hline Yes & 1,183 & 82.1 \\
\hline Not a dejure resident & 60 & 4.2 \\
\hline \multicolumn{3}{|l|}{ Frequency of watching television } \\
\hline Not at all & 77 & 5.3 \\
\hline Less than once a week & 199 & 13.8 \\
\hline At least once a week & 1,165 & 80.8 \\
\hline \multicolumn{3}{|l|}{ Owns a mobile telephone } \\
\hline No & 282 & 19.6 \\
\hline Yes & 1,159 & 80.4 \\
\hline \multicolumn{3}{|c|}{ Frequency of using internet last month } \\
\hline Not at all & 739 & 51.3 \\
\hline Less than once a week & 57 & 4 \\
\hline At least once a week & 138 & 9.6 \\
\hline Almost every day & 507 & 35.2 \\
\hline \multicolumn{3}{|l|}{ Wealth index } \\
\hline Poorest & 332 & 23 \\
\hline Poor & 303 & 21 \\
\hline Middle & 263 & 18.3 \\
\hline Richer & 267 & 18.5 \\
\hline Richest & 276 & 19.2 \\
\hline \multicolumn{3}{|c|}{$\begin{array}{l}\text { Had problem with getting money needed for } \\
\text { treatment in health facility }\end{array}$} \\
\hline Big problem & 231 & 16 \\
\hline Not a big problem & 1,210 & 84 \\
\hline \multicolumn{3}{|c|}{ Had problem with distance to health facility } \\
\hline Big problem & 198 & 13.7 \\
\hline Not a big problem & 1,243 & 86.3 \\
\hline \multicolumn{3}{|l|}{ Type of toilet facility } \\
\hline Private: with septic tank & 1,009 & 70 \\
\hline Private: with no septic tank & 135 & 9.4 \\
\hline Shared/public & 134 & 9.3 \\
\hline River/stream/creek & 77 & 5.3 \\
\hline Beach & 11 & 0.8 \\
\hline Pool/ponds & 5 & 0.3 \\
\hline Pit & 35 & 2.4 \\
\hline Yard/bush/forest & 35 & 2.4 \\
\hline
\end{tabular}

\section{MAD}

A child is considered to meet the MAD if the child met the criteria in MDD and MMF. In this study, children who met the MMF were higher than children who met the MDD, respectively, $75.9 \%$ and $35.7 \%$. 
Table 4: Characteristics of parents

\begin{tabular}{lll}
\hline Characteristics & Frequency $(\mathrm{n}=1,441)$ & Percentages \\
\hline Father's occupation & & \\
Did not work & 10 & 0.7 \\
Professional/technical/managerial & 143 & 9.9 \\
Clerical & 121 & 8.4 \\
Sales & 224 & 15.5 \\
Agricultural self-employed & 348 & 24.1 \\
Industrial worker & 333 & 23.1 \\
Services & 250 & 17.3 \\
Other & 8 & 0.6 \\
Don't know & 4 & 0.3 \\
Mother's occupation & & \\
Did not work & 773 & 53.6 \\
Professional/technical/managerial & 134 & 9.3 \\
Clerical & 75 & 5.2 \\
Sales & 203 & 14.1 \\
Agricultual self-employed & 105 & 7.3 \\
Industrial worker & 66 & 4.6 \\
Services & 84 & 5.8 \\
Don't know & 1 & 0.1 \\
Father's education & & \\
Primary & 334 & 23.2 \\
Junior high & 290 & 20.1 \\
Senior high & 554 & 38.4 \\
Academy & 50 & 3.5 \\
University & 211 & 14.6 \\
Don't know & 2 & 0.1 \\
Mother's education & 16 & 1.1 \\
No education & 288 & 20 \\
Primary & 317 & 22 \\
Junior high & 515 & 35.7 \\
Senior high & 88 & 6.1 \\
Academy & 217 & 15.1 \\
University & & \\
\hline & &
\end{tabular}

Meanwhile, the percentage of children who met the MAD in this study was 29\% (Tables 2 and 5).

Table 5: Prevalence of MDD, MMF, and MAD in 6-11-month-old children

\begin{tabular}{lll}
\hline Indicators & $\mathrm{n}$ & Percentages \\
\hline Minimum dietary diversity & 515 & 35.7 \\
$\quad$ Met & 926 & 64.3 \\
$\quad$ Not-met & & 75.9 \\
Minimum meal frequency & 1,093 & 24.1 \\
$\quad$ Met & 348 & 29 \\
$\quad$ Not-met & 418 & 71 \\
Minimum acceptable diet & 1,023 & \\
$\quad$ Met & Not-met &
\end{tabular}

\section{Bivariate association between parent's education and MAD}

The mother's highest educational level was found to be significant with MAD of 6-11-month-old infant $(p=0.032)$. Compared with mothers who did not get education, mothers with higher educational levels were 9.335 times more likely to feed the child with MAD (Table 2). The father's highest educational level was also found to be significant with MAD especially those fathers who graduated from secondary $(p=0.019)$ and higher $(<0.001)$ educational level. The odds ratio of fathers who graduated from the secondary and higher to meet the MAD was 1.465 and 2.605 , respectively (Table 3 ).

\section{Bivariate association between parent's occupation and MAD}

No significant association was found between father's occupation and meeting MAD. Nonetheless, a significant association was observed between mother's occupation and meeting MAD. Table 3 shows that mothers who were working in nonagricultural area were 1.742 times more likely to feed the child according to the MAD than mothers who were not working.

\section{Bivariate association between access to information and MAD}

The ownership of television was also significant with MAD. Households that own television were 3.1 times higher in meeting MAD than households that did not have television. Not only television, but the ownership of mobile phone was also significant with MAD $(p<0.001$; OR = 1.786). Households that watch television less than once a week and at least once a week were also significantly related with MAD. Compared with households that did not watch television at all, households who watched television less than once and at least once a week were, respectively, 3.419 and 3.205 times higher in meeting MAD. The frequency of using the internet was also related to MAD. Households who used the internet almost every day were 2.496 times more likely to meet MAD (Table 3).

\section{Bivariate association between wealth index and MAD}

The richest, richer, and middle wealth index categories were significantly related to the MAD of $6-11$-month-old infants with a $p<0.001$. Compared to households in the poorest wealth index category, the odds ratios of those who were in the middle, richer, and richest categories were 1.678, 2.161, and 4.242, respectively (Table 6).

\section{Bivariate association between access to health facility and MAD}

Households who did not have any problem with getting money for treatment to health facilities were also significantly related to the MAD of 6-11-month-old infants $(p=0.018$; OR $=1.493)$. However, no significant relationship was observed between households who had no problem with distance to the health facility with MAD of $6-11$-month-old infants (Table 6). and MAD

Bivariate association between sanitation

No signification association was observed between type of toilet facility and history of diarrhea and MAD.

\section{Multivariate associations between the factors and MAD}

Factors that are associated with MAD after multivariate analysis were household ownership of 
Table 6: Bivariate analysis between the factors and minimum acceptable diet

\begin{tabular}{|c|c|c|c|c|c|c|}
\hline \multirow[t]{2}{*}{ Variables } & \multicolumn{2}{|l|}{ MAD } & \multirow[t]{2}{*}{$\mathrm{p}$-value } & \multirow[t]{2}{*}{ OR (unadjusted) } & \multicolumn{2}{|c|}{$95 \% \mathrm{Cl}$} \\
\hline & Not-met & Met & & & Lower & Upper \\
\hline \multicolumn{7}{|l|}{ Household has television } \\
\hline No & 173 & 25 & & & & \\
\hline Yes & 817 & 366 & $<0.001$ & $3.100^{*}$ & 2.002 & 4.800 \\
\hline \multicolumn{7}{|l|}{ Frequency of watching television } \\
\hline Not at all & 68 & 9 & & & & \\
\hline Less than once a week & 137 & 62 & $<0.001$ & $3.419^{*}$ & 1.604 & 7.291 \\
\hline At least once a week & 818 & 347 & $<0.001$ & $3.205^{\star}$ & 1.581 & 6.496 \\
\hline \multicolumn{7}{|l|}{ Owns a mobile telephone } \\
\hline No & 225 & 57 & & & & \\
\hline Yes & 798 & 361 & $<0.001$ & $1.786^{*}$ & 1.302 & 2.450 \\
\hline \multicolumn{7}{|l|}{ Uses of internet } \\
\hline Never & 547 & 147 & & & & \\
\hline Yes, last 12 months & 453 & 264 & $<0.001$ & $2.169^{*}$ & 1.711 & 2.749 \\
\hline Yes, before last 12 months & 23 & 7 & 0.778 & 1.133 & 0.477 & 2.691 \\
\hline \multicolumn{7}{|c|}{ Frequency of using internet last month } \\
\hline Not at all & 582 & 157 & & & & \\
\hline Less than once a week & 37 & 20 & 0.017 & $2.004^{*}$ & 1.131 & 3.550 \\
\hline At least once a week & 101 & 37 & 0.149 & 1.358 & 0.896 & 2.058 \\
\hline Almost every day & 303 & 204 & $<0.001$ & $2.496^{*}$ & 1.943 & 3.205 \\
\hline \multicolumn{7}{|l|}{ Wealth index } \\
\hline Poorest & 273 & 59 & & & & \\
\hline Poorer & 231 & 72 & 0.063 & 1.442 & 0.980 & 2.122 \\
\hline Middle & 193 & 70 & 0.010 & $1.678^{*}$ & 1.134 & 2.485 \\
\hline Richer & 182 & 85 & $<0.001$ & $2.161^{*}$ & 1.476 & 3.165 \\
\hline Richest & 144 & 132 & $<0.001$ & $4.242^{*}$ & $2 / 937$ & 6.124 \\
\hline \multicolumn{7}{|c|}{ Had problem with getting money needed for treatment in health facility } \\
\hline Big problem & 179 & 52 & & & & \\
\hline Not a big problem & 844 & 366 & 0.018 & $1.493^{*}$ & 1.071 & 2.081 \\
\hline \multicolumn{7}{|c|}{ Had problem with distance to health facility } \\
\hline Big problem & 149 & 49 & & & & \\
\hline Not a big problem & 874 & 368 & 0.156 & 1.284 & 0.909 & 1.813 \\
\hline \multicolumn{7}{|l|}{ Mother's occupation } \\
\hline Not working & 584 & 189 & & & & \\
\hline Agricultural & 79 & 26 & 0.944 & 1.017 & 0.634 & 1.631 \\
\hline Nonagricultural & 360 & 203 & $<0.001$ & $1.742^{*}$ & 1.374 & 2.210 \\
\hline \multicolumn{7}{|l|}{ Father's occupation } \\
\hline Not working & 9 & 1 & & & & \\
\hline Agricultural & 277 & 71 & 0.431 & 2.307 & 0.288 & 18.509 \\
\hline Nonagricultural & 737 & 346 & 0.172 & 4.225 & 0.533 & 33.482 \\
\hline \multicolumn{7}{|l|}{ Type of toilet facility } \\
\hline Private & & & 0.186 & 1.286 & 0.886 & 1.866 \\
\hline Share & & & 0.76 & 0.597 & 0.338 & 1.056 \\
\hline Nature & & & & & & \\
\hline Mother's highest educational le & & & & & & \\
\hline No education & 15 & 1 & & & & \\
\hline Primary & 235 & 53 & 0.243 & 3.383 & 0.437 & 26.175 \\
\hline Middle & 238 & 79 & 0.123 & 4.979 & 0.647 & 38.298 \\
\hline Secondary & 347 & 168 & 0.056 & 7.262 & 0.951 & 55.440 \\
\hline Higher & 188 & 117 & 0.032 & $9.335^{\star}$ & 1.217 & 71.603 \\
\hline Father's highest educational le & & & & & & \\
\hline Primary & 261 & 73 & & & & \\
\hline Middle & 216 & 74 & 0.283 & 1.225 & 0.846 & 1.774 \\
\hline Secondary & 393 & 161 & 0.019 & 1.465 & 1.066 & 2.013 \\
\hline Higher & 151 & 110 & $<0.001$ & $2.605^{\star}$ & 1.822 & 3.723 \\
\hline Don't know & 2 & 0 & & & & \\
\hline History of diarrhea & & & & & & \\
\hline Yes, past 2 weeks & 194 & 68 & & & & \\
\hline No & 829 & 350 & 0.229 & 1.204 & 0.890 & 1.631 \\
\hline
\end{tabular}

television, wealth index, and mother's occupation. The household that had a television in their house was 2 times more likely to meet the MAD ( $p=0.011$; AOR: 2.048; 95\% Cl = 1.175-3.570). Household in the richest category was also associated with meeting MAD ( $p=0.003 ;$ AOR = 2.205; 95\% Cl = 1.317-3.693). Mothers who were working in the agricultural sector were also significantly related to MAD and 1.6 times more likely to meet the MAD ( $p=0.047$; AOR $=1.683 ; 95 \% \mathrm{Cl}=1.008-2.812)($ Table 7$)$.

\section{Discussion}

Based on the result of this study, we found that factors associated with MAD were wealth index, ownership of television, and mother's occupation. The coverage of MAD among 6-11-month-old children in Indonesiawas 29\%.Asignificant differencewas observed between the MAD prevalence of 6-11-month-old children in the UNICEF Global Database and this study. Based on the UNICEF Global Database, the prevalence of MAD in 6-11-month-old children was $26.3 \%$ using the 2017 IDHS data [10]. This occurred due to the difference in the sample size because of the elimination of missing value from variables that were used in this study. There were $>70 \%$ of $6-11$-month-old children in Indonesia who did not receive MAD. Other studies in different countries showed that the prevalence of MAD was low due to the high prevalence of MMF but low in MDD [26], [27]. The study in Tanzania showed that the prevalence of MAD was significantly lower in 6-11-month-old age group than the older age group and increased with age [27]. Rather than the frequency of food given, the low prevalence of MAD in Indonesia ensued because most of the 6-11-month-old children 
Table 7: Multivariate analysis between factors and minimum acceptable diet

\begin{tabular}{|c|c|c|c|c|}
\hline \multirow[t]{2}{*}{ Variables } & \multirow[t]{2}{*}{$\mathrm{p}$-value } & \multirow[t]{2}{*}{ AOR } & \multicolumn{2}{|l|}{$95 \% \mathrm{Cl}$} \\
\hline & & & Lower & Upper \\
\hline \multicolumn{5}{|l|}{ Household has television } \\
\hline \multicolumn{5}{|l|}{ No } \\
\hline Yes & 0.011 & $2.048^{*}$ & 1.175 & 3.570 \\
\hline \multicolumn{5}{|l|}{ Frequency of watching television } \\
\hline \multicolumn{5}{|l|}{ Not at all } \\
\hline Less than once a week & 0.086 & 2.051 & 0.904 & 4.657 \\
\hline At least once a week & 0.340 & 1.476 & 0.663 & 3.286 \\
\hline \multicolumn{5}{|l|}{ Owns a mobile telephone } \\
\hline \multicolumn{5}{|l|}{ No } \\
\hline Yes & 0.816 & 0.957 & 0.659 & 1.389 \\
\hline \multicolumn{5}{|l|}{ Use of internet } \\
\hline Yes, past 12 months & 0.958 & 0.965 & 0.259 & 3.602 \\
\hline Yes, before the past 12 months & 0.903 & 0.947 & 0.390 & 2.299 \\
\hline \multicolumn{5}{|l|}{ No } \\
\hline \multirow{2}{*}{\multicolumn{5}{|c|}{ Frequency of using internet past month }} \\
\hline Not at all & & & & \\
\hline Less than once a week & 0.459 & 1.709 & 0.414 & 7.066 \\
\hline At least once a week & 0.980 & 1.018 & 0.260 & 3.984 \\
\hline Almost every day & 0.542 & 1.514 & 0.400 & 5.733 \\
\hline \multicolumn{5}{|l|}{ Wealth index } \\
\hline \multicolumn{5}{|l|}{ Poorest } \\
\hline Poorer & 0.827 & 1.052 & 0.670 & 1.650 \\
\hline Middle & 0.587 & 1.144 & 0.704 & 1.858 \\
\hline Richer & 0.223 & 1.354 & 0.831 & 2.207 \\
\hline Richest & 0.003 & 2.205 & 1.317 & 3.693 \\
\hline \multicolumn{5}{|c|}{$\begin{array}{l}\text { Had problem with getting money needed for treatment } \\
\text { in the health facility }\end{array}$} \\
\hline $\begin{array}{l}\text { Big problem } \\
\text { Not a big problem }\end{array}$ & 0.868 & 1.031 & 0.721 & 1.474 \\
\hline \multicolumn{5}{|l|}{ Mother's occupation } \\
\hline \multicolumn{5}{|l|}{ Not working } \\
\hline Agricultural & 0.047 & $1.683^{*}$ & 1.008 & 2.812 \\
\hline Nonagricultural & 0.055 & 1.307 & 0.994 & 1.718 \\
\hline \multicolumn{5}{|l|}{ Mother's highest educational level } \\
\hline \multicolumn{5}{|l|}{ No education } \\
\hline Primary & 0.390 & 2.518 & 0.307 & 20.675 \\
\hline Middle & 0.276 & 3.236 & 0.391 & 26.807 \\
\hline Secondary & 0.210 & 3.876 & 0.465 & 32.292 \\
\hline Higher & 0.340 & 2.839 & 0.333 & 24.241 \\
\hline \multicolumn{5}{|l|}{ Father's highest educational level } \\
\hline Primary & & & & \\
\hline Middle & 0.613 & 0.901 & 0.601 & 1.351 \\
\hline Secondary & 0.241 & 0.793 & 0.539 & 1.168 \\
\hline Higher & 0.653 & 1.121 & 0.681 & 1.845 \\
\hline
\end{tabular}

did not receive diverse diet that could be seen on the low prevalence of MDD and higher prevalence of MMF (Table 5). This also occurred in the previous national survey, 2012 IDHS, that the low prevalence of MAD of $6-11$-month-old children ensued from the low level of MDD and high level of MMF [10].

According to the UNICEF's conceptual framework of determinants of child undernutrition, one of the basic causes of undernutrition is economic factor. Financial inadequacy or any financial issue could affect the household's access to adequate resources as regards quality and quantity including education, income, technology, land, and employment [2]. In this study, wealth index was used as the proxy to represent the household financial condition due to limited available data. Wealth index is a measurement of the household's wealth level without using neither income nor outcome data but instead using the household's asset availability and house characteristic data that can be used to portray long-term economic status [28], [29], [30], [31]. The findings about wealth index as a significant factor related to MAD were consistent with similar studies in India and other countries [20], [21], [26]. A study in India showed that household in the poorest quintile had the greatest risk of not meeting the MAD compared to the other quintile that could occur due to food insecurity and traditional barrier [20]. Another study in Indonesia also showed that wealth index and urban-rural location are also associated with MAD, and the study result implied that wealth and living in urban areas determine access to resources that will meet the child's adequate feeding practices [11]. Results from this study showed that wealth index was found to be associated with MAD. Children from richer household were more likely to achieve MAD due to the ease of access and increased ability and purchasing power of variety foods and frequency of food given to the child. Household with richer wealth index could have wider option of food that could be chosen and consumed especially in animal protein that is considered as an expensive food. In our study, 6-11-month-old children in the poorest category who consumed animal protein including meat and eggs were $31.4 \%$ and $27.7 \%$, respectively, whereas the percentage of children in the richest category who were given meat and eggs were $49.3 \%$ and $32.6 \%$, respectively.

In this study, the final models showed that mothers who were working in the agricultural sector were significantly related to MAD and had higher risk of achieving MAD. Studies from different countries were found to be consistent with this study showing that a significant association was observed between working mothers and MAD [32], [33]. A study in Pakistan also showed that mothers who worked in the agricultural sector have 11.39 times more diverse diet than mothers who were not working [29]. The agricultural workers mostly lived near the area of the land where they are working. This suggests that mothers who work in the agricultural sector will have more time to get involved in the child feeding practices. However, achieving MAD in children with agricultural working mothers varies by the household wealth wherein the household that had more assets could reduce their work time and work load in agricultural activities [30], [31]. The result of bivariate and multivariate regression in this study showed that mothers who were working were significantly related to $M A D$ and had higher risk of achieving MAD than nonworking mothers. This finding was not consistent with the previous study conducted in Indonesia that found no significant association between MAD and mother's working status that also implied that working mothers had heavier workload that could reduce mother's involvement in child feeding [11]. Mothers who were working could support the household's income so the children might be given diverse and frequent food.

To represent the access to information, the ownership of television was used as the proxy. The final model of this study showed that the household that owned television was significantly associated with achieving MAD. A previous study reported that infant mothers who watched television at least once a week or every day had higher dietary diversity, meal frequency, and acceptable diet than infant mothers who did not [21]. Studies in South Asian countries 
showed that limited exposure to media was significantly related to poor practice of complementary feeding [34]. Having a television suggested that the mother will be more exposed to the information. Mass media including television played a crucial role in educating mothers and caregiver on appropriate child feeding practices [35]. The Indonesian government under the $\mathrm{MoH}$ had published the public service advertisement about complementary feeding that also had been aired on television stations in Indonesia. The duration of the advertisement was $30 \mathrm{~s}$ that consists of several topics including the definition of complementary feeding, types of food in complementary feeding (staple food, animal-based protein, plant-based protein, vegetables, and fruit), time to give the child complementary feeding, and the consistency of complementary feeding in different age categories [36]. However, the public service advertisement was created in 2018 and had been limited in promoting the frequency of food that should be given to the child. Therefore, to promote the achievement of MAD in 6-11-month-old children in Indonesia, the $\mathrm{MoH}$ should consider on renewing the advertisement and creating another public service advertisement that served as a holistic message on how the complementary food is served.

The low MAD in 6-11-month-old children in Indonesia ensued because most of the children had low diet diversity. Therefore, promoting diet diversity especially in children aged 6-11 months should be improved by the Indonesian government. In spite of the fact that the ability to consume several foods in 6-11-month-old children was limited, giving a diverse diet is still recommended rather than only giving one food group diet including only giving child porridge and chicken stock to fulfill the nutritional needs [36]. The 6-11 months age group is still included in the first 1,000 days of life; thus, fulfilling the nutritional needs by giving food that meet the MAD will support the child's growth and development. Furthermore, intervention based on community-based promotion and strong advocacy by local and national stakeholders that aim in improvement of dietary diversity and MAD should be addressed.

Based on this study, factors that are associated with MAD were wealth index, ownership of television, and mother's occupation. Wealth index was used as the proxy of household's economic status and one of the main factors that are associated with MAD. The government could improve and support the economic status of the public by empowering small and medium enterprises in Indonesia and conducting training events to improve skills. Ownership of television used as the proxy of access to information was also associated with MAD rather than the ownership or the use of internet. Therefore, strong commitment from the Indonesia Broadcasting Commission should ensure the television show that has been broadcasted has a certain quality and delivers the right information. The Directory of
Health Promotion and Community Empowerment in Indonesia also could create an interesting and holistic advertisement on complementary feeding in Indonesia. Partnership from the government with the television station to share health promotion message in their programs that aim to improve children feeding practices could be conducted. Mother's occupation was also associated with MAD in Indonesia. Therefore, protections of women's right in the workplace should be addressed to ensure that women's workplace is safe. Giving breast milk is recommended until children reach 2-years-old and is counted as a food group in MDD. Hence, the workplace should provide lactating rooms for mothers so they could provide breast milk for their children. Support from the workplace, husband, relatives, and community toward working mothers to involve and provide good child feeding practices is needed to ensure that children receive the MAD.

Data from the national scale level survey, IDHS, were used in this study. The sample size was large and representative enough for 6-11-month-old children in Indonesia. To our knowledge, this is the first study to search the determinants of MAD using the 6-11 months age group. Based on how the primary data were obtained, several limitations exist including not giving a clear minimum amount of consumed food/drink that will be counted as consuming because the questionnaire was not doing the 24-h recall but only asking "Did your child eat/drink ... yesterday?" There could be an overestimation because no matter how much the amount of food that was consumed, it will be counted as consuming. Therefore, the MAD indicator should not be portrayed as children's nutritional intake. Since the data only consist of a 1-day food report, this could not be portrayed as the child's eating habit. This survey was also not excluding samples based on the child's health condition that could affect the child's appetite and food intake that will be associated with achieving MAD. The sub-variables that are used to represent the independent variables from this study might be limited due to the availability of data. A study using the other age group and using the new standard in counting the MDD that uses a minimum of $10 \mathrm{~g}$ consumption to be counted as consuming food should be conducted in the future research to find more comprehensive MAD achievement [4].

\section{Conclusions}

In conclusion, factors that are associated with MAD in 6-11-month-old children in Indonesia include wealth index, ownership of television, and mother's occupation. The prevalence of MAD, MDD, and MMF in 6-11-month-old children is $29 \%, 35.7 \%$, and $75.9 \%$. To improve the MAD, program intervention to empower 
mothers or workforce might increase the wealth index of the household. Furthermore, with the high percentage of TV ownership (82\%), a multisectoral and holistic intervention to increase the complementary feeding practices in Indonesia, the government should consider channeling the information through it.

\section{Author Contributions}

Conceptualization, E.Z. and T.M.; investigation, E.Z.; methodology, E.Z., T.M., and D.R.; validation, T.M.; formal analysis, E.Z.; resources, E.Z.; writing-original draft preparation, E.Z.; writing-review and editing, E.Z., T.M., D.R., M.D., S.H., and C.T.Y.; and supervision, T.M., D.R., M.D., S.H., and C.T.Y. All authors have read and agreed to the published version of the manuscript.

\section{Institutional Review Board Statement}

This study was approved by the Ethics Committee from the Faculty of Medicine Universitas Airlangga (KEPK FKUA on June 4, 2021, number 104/ EC/KEPK/FKUA/2021).

\section{Data Availability Statement}

Publicly available 2017 Indonesia Demographic and Health Survey datasets were analyzed in this study. This data can be found here: [http://dhsprogram.com/.]

\section{References}

1. Indonesia Ministry of Health. Studi Status Gizi Balita. Balitbangkes Kemenkes RI; 2019. Available from:https://www.kemkes.go.id/ resources/download/info-terkini/rakerkesnas-2020/02-sideevent/se_08/studistatusgizibalitaterintegrasisusenas2019 (kapuslitbangukm).pdf. [Last accesed on $2021 \mathrm{Apr}$ 14].

2. UNICEF. UNICEF's Approach to Scaling Up Nutrition. New York: UNICEF; 2015. Available from: https://www.unicef.org/nutrition/ files/unicef_nutrition_strategy.pdf. [Last accesed on 2021 Apr 15].

3. UNICEF and WHO. Indicators for Assessing Infant and Young Child Feeding Practices Part 1: Definitions. France: World Health Organization; 2008. Available from: https://www.who.int/ nutrition/publications/infantfeeding/9789241599290/en. [Last accesed on 2021 Apr 19].

4. World Health Organization. Global Nutrition Monitoring
Framework: Operational Guidance for Tracking Progress in Meeting Targets for 2025. Geneva: World Health Organization; 2017. Available from: https://www.who.int/publications/i/ item/9789241513609. [Last accesed on 2021 Apr 14].

5. UNICEF and WHO. Indicators for Assessing Infant and Young Child Feeding Practices Part 2: Measurement. World Health Organization. Malta: World Health Organization; 2010.

6. Puspitasari MD, Gayatri M. Indonesia infant and young child feeding practice: The role of women's empowerment in household domain. Glob J Health Sci. 2020;12(9):129. http:// doi.org/10.5539/gjhs.v12n9p129

7. Yisak H, Ambaw B, Walle Z, Alebachew B, Ewunetei A. Minimum acceptable diet and associated factors among HIV-exposed children aged 6-24 months in Debre Tabor Town, Ethiopia. HIV AIDS (Auckl). 2020;12:639-45. http://doi.org/10.2147/HIV. S274764

\section{PMid:33149697}

8. White JM, Bégin F, Kumapley R, Murray C, Krasevec J. Complementary feeding practices: Current global and regional estimates. Matern Child Nutr. 2017;13(Suppl 2):e12505. http:// doi.org/10.1111/mcn.12505

PMid:29032623

9. UNICEF. Global UNICEF Global Databases: Infant and Young Child Feeding: Minimum Acceptable Diet, Minimum Diet Diversity, Minimum Meal Frequency. New York: UNICEF; 2019. Available from: https://data.unicef.org/topic/nutrition/infant-andyoung-child-feeding. [Last accesed on 2020 Oct 20].

10. Khanal V, Sauer K, Zhao Y. Determinants of complementary feeding practices among Nepalese children aged 6-23 months: Findings from demographic and health survey 2011. BMC Pediatr. 2013;13(1):131

11. Santika $O$, Februhartanty J, Ariawan I. Feeding practices of young children aged 12-23 months in different socioeconomic settings: A study from an urban area of Indonesia. $\mathrm{Br} J$ Nutr. 2016;116(S1):S1-7. http://doi.org/10.1017/ S0007114515003438

PMid:26388172

12. Issaka Al, Agho KE, Page AN, Burns PL, Stevens GJ, Dibley MJ. Determinants of suboptimal complementary feeding practices among children aged 6-23 months in four anglophone West African countries. Matern Child Nutr. 2015;11(Suppl 1):14-30. http://doi.org/10.1111/mcn.12194

PMid:26364789

13. Kabir I, Khanam M, Agho KE, Mihrshahi S, Dibley MJ, Roy SK. Determinants of inappropriate complementary feeding practices in infant and young children in Bangladesh: Secondary data analysis of demographic health survey 2007. Matern Child Nutr. 2012;8(Suppl 1):11-27. http://doi.org/10.1111/j.1740-8709.2011.00379.x PMid:22168516

14. Ahmed KY, Page A, Arora A, Ogbo FA. Trends and factors associated with complementary feeding practices in Ethiopia from 2005 to 2016. Matern Child Nutr. 2020;16(2):e12926. http://doi.org/10.1111/mcn.12926

PMid:31833239

15. Mulat E, Alem G, Woyraw W, Temesgen H. Uptake of minimum acceptable diet among children aged 6-23 months in orthodox religion followers during fasting season in rural area, DEMBECHA, North West Ethiopia. BMC Nutr. 2019;5:18. http:// doi.org/10.1186/s40795-019-0274-y PMid:32153931

16. Olatona FA, Adenihun JO, Aderibigbe SA, Adeniyi OF. Complementary feeding knowledge, practices, and dietary diversity among mothers of under-five children in an Urban Community in Lagos State, Nigeria. Int $\mathrm{J} \mathrm{MCH}$ AIDS. 
2017;6(1):46-59. http://doi.org/10.21106/ijma.203 PMid:28798893

17. Tassew AA, Tekle DY, Belachew AB, Adhena BM. Factors affecting feeding 6-23 months age children according to minimum acceptable diet in Ethiopia : A multilevel analysis of the Ethiopian demographic health survey. PLoS One. 2019;14(2):e0203098. http://doi.org/10.1371/journal.pone.0203098 PMid:30789922

18. Patel A, Pusdekar Y, Badhoniya N, Borkar J, Agho KE, Dibley MJ Determinants of inappropriate complementary feeding practices in young children in India: Secondary analysis of National Family Health Survey 2005-2006. Matern Child Nutr. 2012;8(Suppl 1):2844. http://doi.org/10.1111/j.1740-8709.2011.00385.x PMid:22168517

19. Joshi N, Agho KE, Dibley MJ, Senarath U, Tiwari K. Determinants of inappropriate complementary feeding practices in young children in Nepal: Secondary data analysis of demographic and health survey 2006. Matern Child Nutr. 2012;8(Suppl 1):45-59. http://doi.org/10.1111/j.1740-8709.2011.00384.x PMid:22168518

20. Dagne $\mathrm{AH}$, Anteneh $\mathrm{KT}$, Badi $\mathrm{MB}$, Adhanu $\mathrm{HH}$, Ahunie MA, Tebeje HD, et al. Appropriate complementary feeding practice and associated factors among mothers having children aged 6-24 months in Debre Tabor Hospital, North West Ethiopia, 2016. BMC Res Notes. 2019;12(1):215. http://doi.org/10.1186/ s13104-019-4259-3 PMid:30961638

21. Ahmad A, Madanijah S, Dwiriani CM, Kolopaking $R$. Complementary feeding practices and nutritional status of children 6-23 months old: Formative study in Aceh, Indonesia. Nutr Res Pract. 2018;12(6):512-20. http://doi.org/10.4162/ nrp.2018.12.6.512

PMid:30515279

22. Limardi S, Hasanah DM, Utami NM, Sidiartha IG. Investigating the effect of unachieved minimum acceptable diet and low infant and child feeding index as risk factors of stunting in children aged 6-23 months. Paediatr Indones. 2020;60(5):259-68.

23. Statistics Indonesia. Peraturan Kepala Badan Pusat Statistik No. 103 Tahun 2016 Tentang Pedoman Teknis Badan Pusat Statistik Provinsi dan Badan Pusat Statistik Kabupaten/Kota dalam Rangka Survei Demografi dan Kesehatan Indonesia, Jakarta 2017.

24. Statistics Indonesia. Profil Kesehatan Indonesia Tahun; 2017. Available from: https://pusdatin.kemkes.go.id/resources/ download/pusdatin/profil-kesehatan-indonesia/profilkesehatan-indonesia-tahun-2017.pdf. [Last accesed on 2021 May 14].

25. National Population and Family Planning Board (BKKBN), Statistics Indonesia (BPS), Ministry of Health (Kemenkes) and II. Indonesia 2017 DHS; 2017. p. 588.

26. Na M, Aguayo VM, Arimond M, Stewart CP. Risk factors of poor complementary feeding practices in Pakistani children aged 6-23 months: A multilevel analysis of the demographic and health survey 2012-2013. Matern Child Nutr. 2017;13(Suppl 1):e12463.

27. Victor R, Baines SK, Agho KE, Dibley MJ. Factors associated with inappropriate complementary feeding practices among children aged 6-23 months in Tanzania. Matern Child Nutr. 2014;10(4):545-61. http://doi. org/10.1111/j.1740-8709.2012.00435.x

PMid:22925557

28. Filmer D, Pritchett LH. Estimating wealth effects without expenditure data or tears: An application to educational enrollments in states of India. Demography. 2001;38(1):115-32. http://doi.org/10.1353/dem.2001.0003

PMid: 11227840

29. Khan GN, Ariff S, Khan U, Habib A, Umer M, Suhag Z, et al Determinants of infant and young child feeding practices by mothers in two rural districts of Sindh, Pakistan: A crosssectional survey. Int Breastfeed J. 2017;12(1):40. http://doi. org/10.1186/s13006-017-0131-z PMid:28936229

30. Ickes SB, Hurst TE, Flax VL. Maternal literacy, facility birth, and education are positively associated with better infant and young child feeding practices and nutritional status among Ugandan children. J Nutr. 2015;145(11):2578-86. http://doi.org/10.3945/ jn. 115.214346 PMid:26377762

31. Ali M, Arif $M$, Shah AA. Complementary feeding practices and associated factors among children aged 6-23 months in Pakistan. PLoS One. 2021;16(2):e0247602. http://doi. org/10.1371/journal.pone.0247602

PMid:33630931

32. Komatsu H, Malapit HJ, Theis S. Does women's time in domestic work and agriculture affect women's and children's dietary diversity? Evidence from Bangladesh, Nepal, Cambodia, Ghana, and Mozambique. Food Policy. 2018;79:256-70.

33. Paramashanti BA, Benita S. Early introduction of complementary food and childhood stunting were linked among children aged 6-23 months. J Gizi Klin Indones. 2020;17(1):1.

34. Senarath U, Agho KE, Akram DS, Godakandage SS, Hazir T, Jayawickrama $\mathrm{H}$, et al. Comparisons of complementary feeding indicators and associated factors in children aged 6-23 months across five South Asian countries. Matern Child Nutr. 2011;8(Suppl 1):89-106. http://doi. org/10.1111/j.1740-8709.2011.00370.x PMid:22168521

35. Ministry of Health. Complementary Feeding Public Service Advertisment. Ministry of Health: Director of Health Promotion and Community Empowerment; 2019. Available from: https:// promkes.kemkes.go.id/tv-spot-mp-asi [Last accesed on 2021 May 27].

36. PAHO, World Health Organization. Guiding Principles for Complimentary Feeding of the Breastfed Child. Washington, DC: World Health Organization; 2003. Available from: https:// www.who.int/maternal_child_adolescent/documents/a85622/en 